University of Nebraska - Lincoln

DigitalCommons@University of Nebraska - Lincoln

Faculty Publications from the Harold W. Manter Laboratory of Parasitology

$12-1976$

\title{
Two Tetraphyllidean Cestodes from the Freshwater Stingray Potamotrygon magdalenae Dumeril 1852 (Chondrichthyes: Potamotrygonidae) from Colombia
}

\author{
Daniel R. Brooks \\ University of Toronto,dnlbrooks@gmail.com \\ Thomas B. Thorson \\ University of Nebraska - Lincoln
}

Follow this and additional works at: https://digitalcommons.unl.edu/parasitologyfacpubs

Part of the Parasitology Commons

Brooks, Daniel R. and Thorson, Thomas B., "Two Tetraphyllidean Cestodes from the Freshwater Stingray Potamotrygon magdalenae Dumeril 1852 (Chondrichthyes: Potamotrygonidae) from Colombia" (1976). Faculty Publications from the Harold W. Manter Laboratory of Parasitology. 214.

https://digitalcommons.unl.edu/parasitologyfacpubs/214

This Article is brought to you for free and open access by the Parasitology, Harold W. Manter Laboratory of at DigitalCommons@University of Nebraska - Lincoln. It has been accepted for inclusion in Faculty Publications from the Harold W. Manter Laboratory of Parasitology by an authorized administrator of DigitalCommons@University of Nebraska - Lincoln. 


\title{
TWO TETRAPHYLLIDEAN CESTODES FROM THE FRESHWATER STINGRAY POTAMOTRYGON MAGDALENAE DUMERIL 1852 (CHONDRICHTHYES: POTAMOTRYGONIDAE) FROM COLOMBIA*
}

\author{
Daniel R. Brooks \\ Gulf Coast Research Laboratory, P.O. Box A.G., Ocean Springs, Mississippi 39564 and
}

Thomas B. Thorson

School of Life Sciences, University of Nebraska-Lincoln, Lincoln, Nebraska 68588

ABSTRACT: Two new tetraphyllidean cestodes are described from the freshwater stingray Potamotrygon magdalenae from Colombia. The new genus Potamotrygonocestus is proposed for P. magdalenensis, which differs from Pedibothrium by having a bilobed rather than X-shaped ovary, and simple rather than bifid hooks. It further differs from Pachybothrium hutsoni by having bothridial hooks inserted immediately posterior to an accessory sucker rather than inserted in the middle of a thick muscular pad. Potamotrygonocestus magdalenensis is unique among known tetraphyllideans by possessing vitellaria which are compact, cylindrical bands in the lateral portions of the middle of the proglottid. The second new species, Rhinebothrium moralarai, resembles $R$. scorzai by having its genital pore and terminal genitalia at the ovarian level, greatly reduced poral ovarian lobes, and by parasitizing a freshwater stingray. It differs from $R$. scorzai in number of bothridial loculi, testes per proglottid, and proglottids per strobila; by having quadrate rather than canoe-shaped bothridia; and by parasitizing Potamotrygon magdalenae rather than $P$. hystrix.

During June 1975 the authors studied the freshwater stingray Potamotrygon magdalenae Dumeril 1852 in the Magdalena River system of the Republic of Colombia. Fifteen of the rays from three localities were examined for helminths. Among the helminths collected were specimens of two tetraphyllidean cestodes described as new in this report.

Worms were fixed in situ or removed from the host spiral valve, studied alive, and fixed with AFA. All were immediately transferred to $70 \%$ ethanol for storage. Whole mounts were stained with Ehrlich's acid hematoxylin and mounted in Histoclad. Serial cross-sections, cut at $8 \mu \mathrm{m}$, were used to confirm some aspects of proglottid morphology. Host specimens remain in the second author's collection. Measurements are in micrometers unless otherwise stated; figures were drawn with the aid of a drawing tube.

\section{Potamotrygonocestus gen. n.}

Diagnosis: Tetraphyllidea; Onchobothriidae. Scolex with 4 sessile, nonseptate bothridia, each with simple margins, accessory sucker, and pair of simple hooks. Cephalic peduncle absent. Ovary bilobed in cross-section. Vitellaria lateral, compact, cylin-

Received for publication 25 November 1975.

* Funds for this study were provided through a grant from the National Geographic Society to the second author. drical. Parasites of elasmobranchs. Type and only species:

\section{Potamotrygonocestus magdalenensis sp. n.} (Figs. 1-4)

Description (based on 9 complete worms and 12 free proglottids): Strobila acraspedote, hyperapolytic, 1.0 to $2.1 \mathrm{~mm}$ long, composed of 7 to 10 proglottids. Internal musculature as follows: single layer of bundles of longitudinal muscles immediately below basement membrane of tegument; circular cortical muscles poorly-developed; ring of longitudinal muscle bundles central to circular muscles. Scolex 145 to 160 long by 242 to 293 wide; bothridia 174 to 241 long by 110 to 160 wide; accessory suckers 20 to 32 in diameter. Hook prongs 43 to 55 long, bases 19 to 29 long. Neck 87 to 203 long. Scolex and neck spinose; spines 5 to 15 long. Immature proglottids initially wider than long, becoming longer than wide; mature detached ones 0.80 to $1.30 \mathrm{~mm}$ long by 0.25 to 0.50 $\mathrm{mm}$ wide. Testes in two longitudinal rows in anterior $2 / 3$ of proglottid, 20 to 29 in number, 47 to 87 in diameter. Cirrus sac near posterior end of proglottid, 47 to 87 long by 29 to 58 wide, containing spined eversible cirrus. Everted cirrus 145 to 203 long by 23 wide. Genital atrium absent; genital pores dextral or sinistral. Vagina anterior to cirrus sac with dorsal tegumental membrane. Ovary in posterior $1 / 3$ of proglottid, 204 to 360 long by 75 to 204 wide at isthmus; ovarian lobes fused posteriorly. Gravid detached proglottids 1.3 to 1.7 $\mathrm{mm}$ long by 0.4 to $0.6 \mathrm{~mm}$ wide. Uterus saccate, without lateral branches. Vitellaria extending from level of ovarian isthmus to within 25 to $35 \%$ of proglottid length of anterior end. Eggs spherical, 10 to 17 in diameter, unembryonated. Excretory 

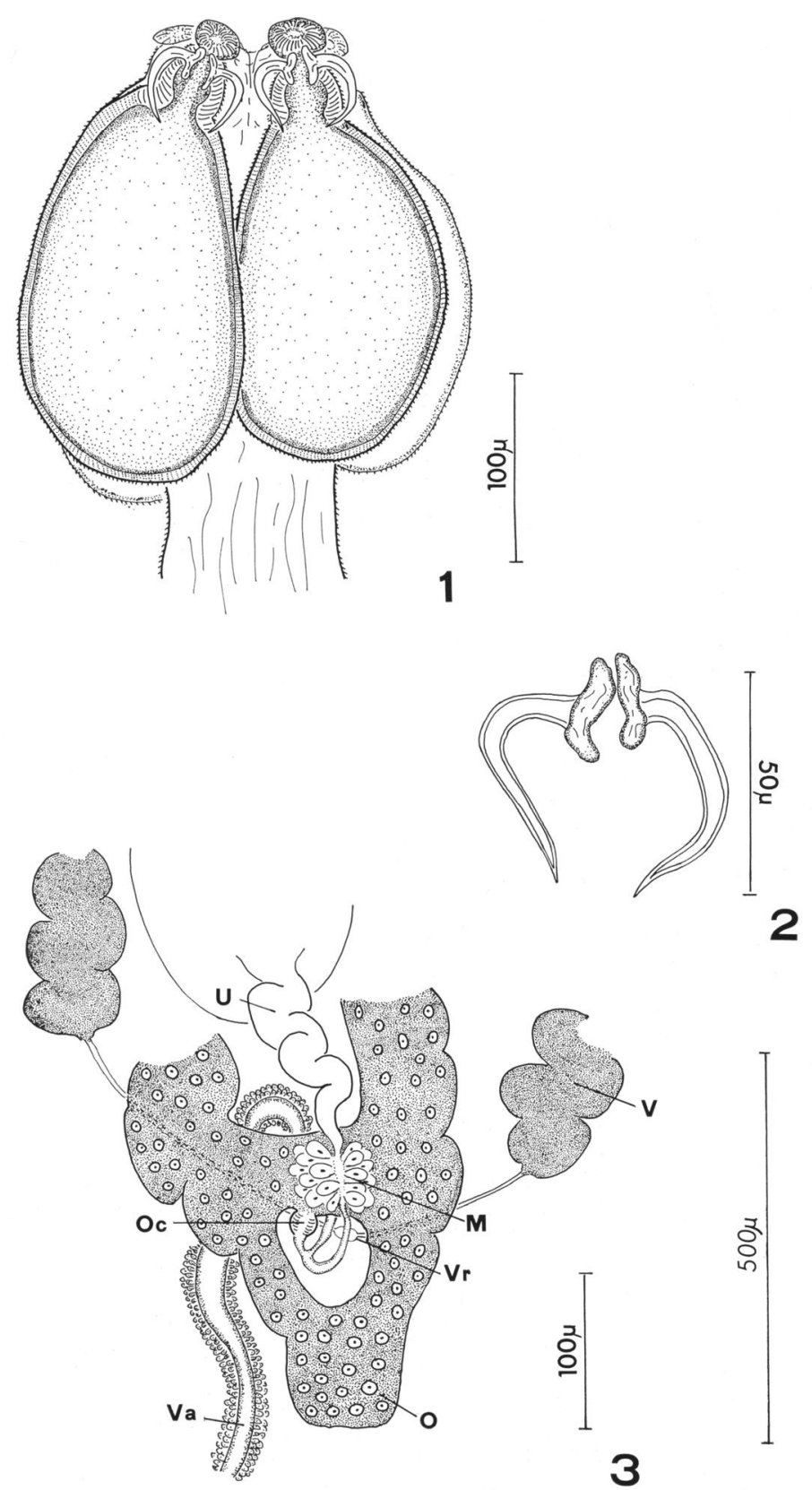

Figures 1-4. Potamotrygonocestus magdalensis. 1. Scolex. 2. Bothridial hooks. 3. Ootype region. 4. Mature proglottid. Abbreviations: C, cirrus sac; Esv, external seminal vesicle; Ga, genital atrium; Isv, internal seminal vesicle; M, Mehlis' gland; Oc, oocapt; Od, oviduct; Sr, seminal receptacle; U, uterus; V, vitellarium; Va, vagina; Vd, vas deferens; Vr, vitelline receptacle.

FIgUREs 5-10. Rhinebothrium moralarai. 5. Immature worm. 6. Plan of bothridial loculi. 7. Ootype region. 8. Mature proglottid. 9. Terminal genitalia. 10. Gravid proglottid. 

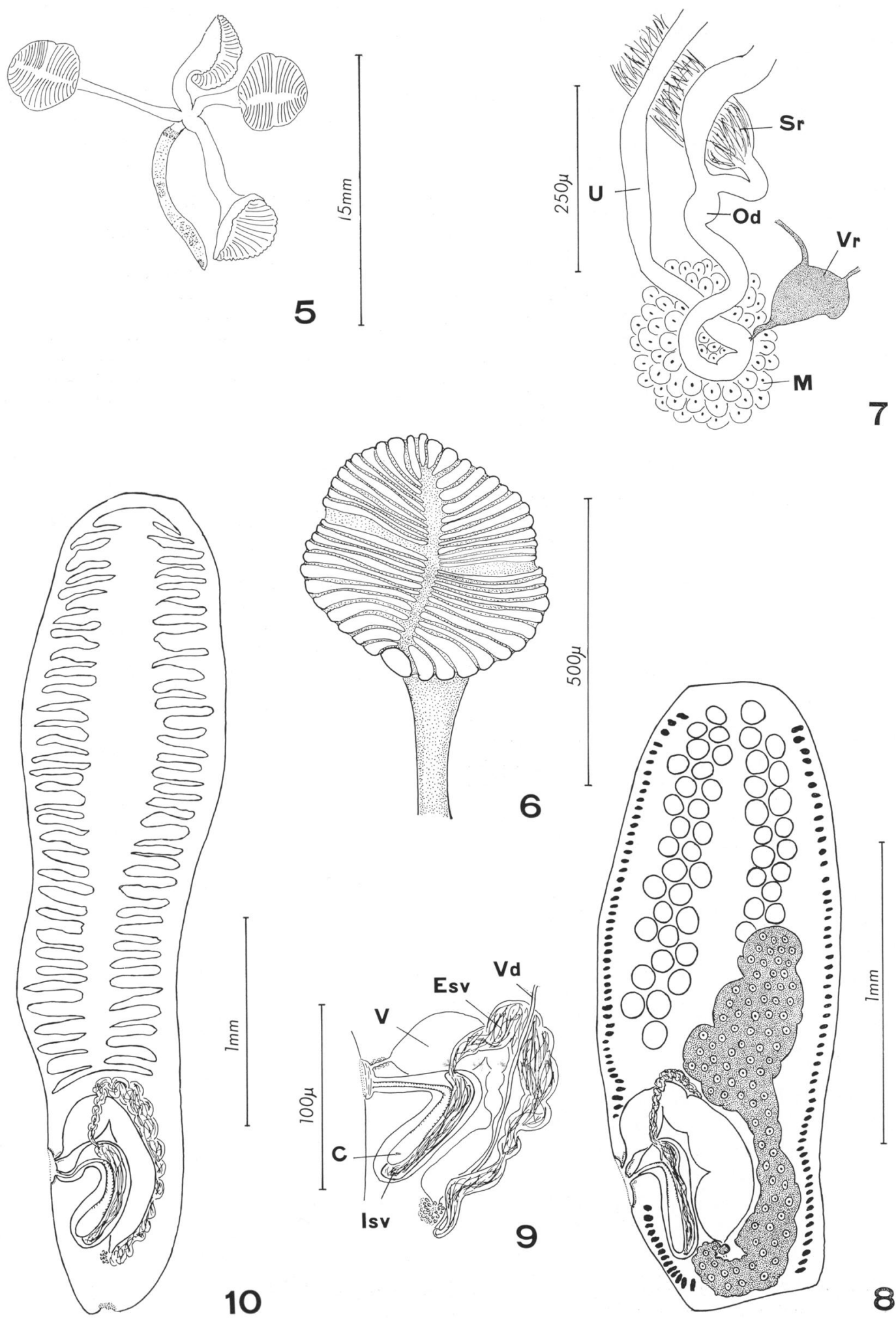
system composed of paired smaller dorsal and larger ventral longitudinal medullary ducts, and associated reticulate network of cortical tubules.

Host: Potamotrygon magdalenae.

Site of infection: Anterior portion of spiral valve. Locality: Cienaga Rabón, vicinity of San Cristóbal, Bolívar, Colombia.

Holotype: USNM Helm. Coll. No. 73542. Paratypes: USNM Helm. Coll. No. 73543; Univ. Neb. State Mus. H. W. Manter Lab. No. 20254.

Etymology: The generic name means cestodes of Potamotrygon, while the specific name refers to the river system from which the hosts were collected.

\section{Remarks}

Potamotrygonocestus magdalenensis most closely resembles species of Pedibothrium Linton 1909 and the poorly-known Pachybothrium hutsoni (Southwell 1911) Baer and Euzet 1962. It differs from Pedibothrium species by having simple rather than bifid hooks, a bilobed rather than X-shaped ovary, and by parasitizing a freshwater stingray rather than a nurse shark. Potamotrygonocestus magdalenensis differs from Pachybothrium hutsoni by having the bothridial hooks inserted posterior to the apical suckers rather than inserted in the middle of a thick muscular pad. Further, Baer and Euzet (1962) stated than Pachybothrium hutsoni resembled species of Pedibothrium by lacking a postporal testicular field; Potamotrygonocestus magdalenensis has testes arranged in two longitudinal rows occupying the entire preovarian space. Neither Southwell (1911) nor Baer and Euzet (1962) presented data on the structure of the ovary of Pachybothrium hutsoni; we have unsuccessfully attempted to obtain specimens from Dr. L. Euzet. Despite our lack of knowledge concerning the ovarian lobes of $P$. hutsoni, we propose the new genus on the basis of the bothridial armature and testicular configuration. The vitellaria of Potamotrygonocestus magdalenensis, viewed in whole mounts or cross-section, appear as two lateral, cylindrical, compact masses occupying the middle half of the proglottid. Those of most tetraphyllideans are follicular and irregularly V-shaped, or form a circumcortical ring of follicles when viewed in cross-section.

Hamilton and Byram (1974) reported that urea was instrumental in providing the stimulus for initiation of production of adult scolex features, including bothridial hooks, in plerocercoids of species of the genus Acanthobothrium van Beneden 1850. Considering the inability of freshwater stingrays to concentrate urea, demonstrated by Thorson (1970), it may be that the stimulus for production of bothridial hooks in Potamotrygonocestus magdalenensis is different than that for marine onchobothriids.

\section{Rhinebothrium moralarai sp. n.} (Figs. 5-10)

Description (based on 15 immature and 10 mature worms ): Strobila acraspedote, apolytic, up to $30 \mathrm{~mm}$ long, composed of 13 to 29 proglottids. Scolex with 4 pedicellated, bilobed, quadrate bothridia; rostellum absent. Pedicels contractile, up to $1.1 \mathrm{~mm}$ long. Bothridia 0.6 to $1.1 \mathrm{~mm}$ long by 0.7 to $1.0 \mathrm{~mm}$ wide; indistinct hingelike constriction between lobes; divided longitudinally by indistinct median septum, transversely by 21 or 22 septa forming 2 parallel rows of 22 or 23 loculi plus terminal loculus at tip of each lobe; total number of loculi 46 or 48 . Immature proglottids wider than long; mature ones 1.0 to $2.8 \mathrm{~mm}$ long by 0.5 to 1.1 $\mathrm{mm}$ wide. Testes in 2 broad fields in anterior $2 / 3$ of proglottid, 54 to 71 in number, 50 to 100 in diameter. Cirrus sac in posterior $1 / 5$ of proglottid, 142 to 176 long, distal end recurved posteriorly; containing spined eversible cirrus and internal seminal vesicle. External seminal vesicle extending length of cirrus sac, joining cirrus sac near poral end and vas deferens near posterior end of proglottid. Genital atrium shallow; genital pores dextral or sinistral. Vagina anterior to cirrus sac; vaginal sphincter present; posterior portion dilated to form seminal receptacle. Ovary bilobed in frontal view, Xshaped in cross-section; aporal lobe 630 to 870 long, extending into anterior $1 / 2$ of proglottid, poral lobe shorter, extending only to posterior margin of cirrus sac. Ovarian isthmus posteromedian to cirrus sac, 110 to 240 wide. Vitelline follicles lateral, extending entire length of proglottid, 10 to 20 in diameter. Gravid proglottids 1.7 to $4.4 \mathrm{~mm}$ long by 0.5 to $1.1 \mathrm{~mm}$ wide, devoid of genitalia; uterus saccate with 53 to 67 total lateral branches. Eggs spherical, 15 to 25 in diameter, unembryonated.

Host: Potamotrygon magdalenae.

Site of infection: Middle portion of spiral valve.

Localities: Cienaga Rabón, vicinity of San Cristóbal, Bolívar, Colombia (type); Cienaga Jobo, vicinity of San Cristóbal; Quebrada Doña Juana, vicinity of La Dorada, Caldas, Colombia.

Holotype: USNM Helm. Coll. No. 73544. Paratypes: USNM Helm. Coll. No. 73545; Univ. Neb. State Mus., H. W. Manter Lab. No. 73546.

Etymology: The species is named in honor of Dr. Orlando Mora Lara, Assistant General Director of Fisheries, INDERENA, Ministry of Agriculture, Republic of Colombia.

\section{Remarks}

Rhinebothrium moralarai is the second member of the genus known to parasitize a fresh- 
water stingray. That species, R. scorzai Lopez-Neyra and Diaz-Ungria, 1958 from Potamotrygon hystrix in Venezuela, resembles R. moralarai by having the genital pore and terminal genitalia at the ovarian level with apparently corresponding reduction in size of the poral ovarian lobes. Rhinebothrium moralarai differs from $R$. scorzai in number of bothridial loculi ( 46 to 48 vs. 120 to 140 ), number of testes ( 54 to 71 vs. 86 to 98 ), and number of proglottids per strobila ( 13 to 26 vs. 78 ), as well as having quadrate rather than canoeshaped bothridia and parasitizing Potamotrygon magdalenae rather than $P$. hystrix. It is not apparent from the original description whether or not $R$. scorzai has an internal seminal vesicle and voluminous external seminal vesicle as does $R$. moralarai (as figured).

Campbell (1970) and Cornford (1974) have reviewed host-specificity among the species of Rhinebothrium, noting that the great majority parasitize myliobatiform elasmobranchs, mostly of the family Dasyatidae. Since dasyatids are considered the closest living relatives of potamotrygonids, we are not surprised to find species of Rhinebothrium in potamotrygonids.

\section{ACKNOWLEDGMENTS}

We express appreciation to the following people: Orlando Mora Lara, INDERENABogota; Guillermo Quiñones Gonzales, Director, Centro de Investigaciones Limnologicos y Piscicola, INDERENA/FAO-San Cristóbal;
Alberto Villaneda, Biologist, INDERENA-LaDorada; Dean Hendrickson, Biologist, INDERENA-Cartegena; Bill Mackay, Peace Corps-Neiva; and Hans Heinrich, Bogota for their aid during the study in Colombia. We also express appreciation to R. A. Campbell, R. M. Overstreet, and T. E. Mattis for their aid and suggestions during the preparation of this manuscript.

\section{LITERATURE CITED}

BAER, J.-G., AND L. Euzet. 1962. Révision critique des cestodes tetraphyllides décrites par T. Southwell (lre partie). Bull Soc Neuchâtel Sci Nat 85: 143-172.

Campbell, R. A. 1970. Notes on tetraphyllidean cestodes from the Atlantic coast of North America, with descriptions of two new species. J Parasitol 56: 498-508.

Cornford, E. 1974. Two tetraphyllidean cestodes from Hawaiian stingrays. J Parasitol 60: 942-948.

Hamilton, K. A., And J. E. Byram. 1974. Tapeworm development: effects of urea on a larval tetraphyllidean. J Parasitol 60 : 20-28.

Lopez-Neyra, C. R., and C. Diaz-Ungrua. 1958. Cestodes de Venezuela. V. Cestodes de vertebrados Venezolanos (segunda nota). Nova Cient 23: 1-41.

Southwell, T. 1911. Descriptions of nine new species of cestode parasites, including two new genera, from marine fishes of Ceylon. Ceylon Mar Biol Bull 5: 216-225.

Thorson, T. B. 1970. Freshwater stingrays, Potamotrygon spp.; failure to concentrate urea when exposed to saline medium. Life Sci 9: 893-900. 